\title{
Developing Materials of Writing Course Using Graphic Organizers for the English Department Students
}

\author{
Tazkiyatunnafs Elhawwa \\ Universitas Islam Malang \\ tazkiyatunnafs.elhawwa@gmail.com
}

\begin{abstract}
The study is intended to develop Writing III Course materials using graphic organizers for the fourth-semester students of English Education Study Program of IAIN Palangka Raya. The Research and Development ( $R$ \& D) design was employed in this study. It included the stages: need analysis, description of the purpose, selection and development of material type, production of proto-material, production of pedagogical material, expert validation, field testing (trying-out), evaluation and revision (evaluation from try-out and the expert, and final product. The final product of this study was the instructional materials (six units for nine meetings) covering introduction to the essay (unit 1 for meetings 1-4), the illustration essay (unit 2 for meeting 5), the classification essay (unit 3 for meeting 6), the process essay (unit 4 for meeting 7), the comparison contrast essay (unit 5 for meeting 8), and the cause and effect (unit 6 for meeting 9). Each unit consisted of learning objective, topic, sub-topic, description, relevancy, and keywords. The materials serve for appropriate topics, clear models, stimulating learning, relevant activities, clear example, graphic organizers, and providing strategies.
\end{abstract}

Keywords: developing, writing course, instructional materials

One of teaching components which is very important in learning process is syllabus. Syllabus is a specification of the content of a course of instruction and lists what will be taught and tested (Richard, 2001:2).

The syllabus usually consists of basic competence, indicators, topics, strategy, assessment, and references. It also includes standard competence. At the top of the syllabus, there is course identity consisting of the name of the course, semester, credits, code, prerequisite, and course description. It is a description and plan for a course and, if well written, may be a tool that improves student learning, facilitates faculty teaching, improves communications between faculty members about their courses, and assists with monitoring program quality.

The syllabus of the 2011 English curriculum consists of basic competence, indicators, topics, strategy, assessment, and references. It also includes competence standard. At the top of the syllabus, there is course identity consisting of the name of the course, semester, credits, code, prerequisite, and course description. Course description of Writing I up to Writing III can be seen in the 2011 English syllabus for the students of English Education Study Program of IAIN Palangka Raya. Writing III 
emphasizes on essay writing, introduction to the essay writing, the structure of an essay, and the development of expository essay such as: example, classification, illustration, comparison and contrast, process, and cause and effect essays. Writing III course is aimed at developing ability to write various essays (Prodi Tadris (Pendidikan) Bahasa Inggris STAIN Palangka Raya, 2011).

Based on this syllabus, the courses which relates to language skills (Listening I, II, and III; Speaking I, II, and III; Reading I, II, and III; and Writing I, II, and III) have to be completed up to the fifth semester by the students. Unlike three other skills, writing course is firstly introduced to the students at the second semester as Writing I. It becomes a basis for going on to the next two writing courses (Writing II and III).

In addition, there have been a number of problems faced by the teachers in the teaching of Writing III. One of them deals with learning materials. Based on the preliminary study conducted by the researcher on Wednesday, February $18^{\text {th }}$, 2015, it was found that the syllabus of learning Writing III material still used the handbook entitled Refining Composition Skill Rhetoric and Grammar (Fifth Edition) written by Smalley \& Ruetten (1986). It was based on the 2011 curriculum of English Education Study Program at IAIN Palangka Raya. Based on the preliminary observation, it was also found that the students got difficulties in understanding and organizing the book, since the book was written by the native speakers. They also got difficulties in understanding the material of each chapter of the book.

The other problem is that the writing materials do not meet the students' needs.
Teachers have difficulties to provide writing materials which are suitable with their students' needs and interest. They also have to find the materials and tasks which are authentic and possible because authentic writing materials and tasks are needed by students to improve their writing skill. As stated by Hyland (2003), students cannot acquire everything they need to improve their writing skill at once, nor can they learn effectively from a random collection of exercises and assignments.

Moreover, writing ability is a learnt skill. It is different from spoken language which can be acquired intuitively by most people. Written form is in most cases deliberately taught and learned (Ur, 1986:161). Hence, the teachers hold the important roles on how to choose the appropriate handbook, how to make the writing class run well, what to teach, and how to assist learners to write.

Hyland (2003) emphasizes that teachers have to develop a systematic plan of what need to be learned, selected and sequenced the contents and the tasks that will lead to desired learning outcome. It can be said that the class cannot go on successfully without precise guidelines. A good material and syllabus will serve as a clear guidance for the teacher to make the teaching plan which specifies the work to be accomplished by the students based on explicit objectives. Therefore, a precise material and syllabus is needed to help both the teacher and the students. In this case, in teaching writing, the writing lecturers are demanded to provide the interesting materials for the students with a good writing foundation in order to make them have adequate proficiency in writing. To achieve this aim, the teachers 
need to provide learning materials that are suitable with students' need and interest. As Tomlinson (2001) states that materials refer to anything which is used by the teachers or learners to facilitate the learning of a language. Materials consist of the knowledge, skills, and attitude that must be learned by the students.

There are a number of reasons to choose the topic. First, based on the students' need and interest the Writing III class needs additional materials that make students easy to learn Writing III. Second, developing materials of Writing III course is needed in order to make easier the material of each chapter of the handbook, make the writing class more interesting, make the teacher more creative in learning process, and increase the quality of Writing III materials. Third, graphic organizers are selected to be the technique of prewriting strategy, since it is assumed that the technique can make the students easy to generate ideas in essay writing. The graphic organizers are also to give benefits to learning process such as in generating ideas, mapping ideas, motivating the students, and creating a positive learning environment.

\section{METHOD}

The Research and Development ( $R$ \& D) design employed, since the study was intended to develop Writing III materials for the fourth-semester students of English Education Study Program of IAIN Palangka Raya. The model of development carried out in the study was similar to Yalden's model known as Language Program Development (Yalden, 1987:88). It was chosen for at least three important reasons. First, the Yalden's model was specially set out for language department, so it could be used to develop course material. Second, it offered gradual procedures which are simple to follow. Third, the model utilized need survey to gain information of students' need and interest.

The study adopted the stages of Yalden's model with some modification (Yalden, 1987:88). First, need survey was carried out to describe the students' needs, interest, shortages as well as the coordinator of English Education Study Program at IAIN Palangka Raya and Writing III teacher's expectation to Writing III course.

Second, description of the purpose was the stage of where the data gathered in the need survey were specified and analyzed. In this stage, need analysis data were the basis to formulate goals and objectives.

Third, the selection of material for Writing III course was based on the result of teacher's successful effort to match all indicators of effective writing material and the objective of writing course. The decision was influenced by what the teacher considered as important to the course and to good writing.

Fourth, a proto-material included the activities of listing and describing the content specification of the syllabus, such as preparation of instructional materials, sources, and evaluation devices.

The next stage, it involved the writing of material contents covering the objectives of the course, the strategies implemented to instruct materials, the evaluation method to be applied to know whether or not the objective have been achieved, and, the time framework of the course. The result was the tentative 
material that was ready for verification to ensure its quality.

Sixth, the developed material was given to the expert for feedback and comments to know whether the material could be categorized as a good material in terms of its compatibility with any relevant materials, methodologies, and evaluation with the course objectives.

Seventh, the try out stage was conducted for the Class $4 \mathrm{~B}$ and $4 \mathrm{D}$ of the fourth-semester students of English Education Study Program at IAIN Palangka Raya who took Writing III course in the even semester. The number of the subject was 48 students.

Eighth, the revision of the product was based on the feedback and comments suggested by the collaborative teacher in the field testing stage. Thus, it was able to achieve its optimal effort in teaching Writing III to the real subject of the study.

The last, the final product of the study was in the form of material to teach Writing III for the fourth-semester students of English Education Study Program at IAIN Palangka Raya. It mainly consisted of course outline, objectives, topics and subtopics selection, methodology, material developed, and evaluation system. To support the materials, the instructional materials for eleven meetings were developed.

The subject of the study consisted of the subjects involved during the need survey process and the subjects in the stage of production of pedagogical materials. The students, the chairman of English Education Study Program at IAIN Palangka Raya, and Writing III lecturers were the subjects engaged in the process of need survey. The data gathered from the students who were taking Writing III course were their wants, needs, interests, and expectations related with Writing III course.

The data of need survey gained from the study were collected through three models of instruments such as questionnaire, written interview, and field note. The questionnaire was distributed to gain the data about needs, interests, shortages, and expectations of both the candidate students who were taking Writing III course. The questionnaire for the study was divided into ten parts.

1. Part one covered the objective of students in taking Writing III.

2. Part two dealt with students' attitude and interest in writing skill.

3. Part three devoted respondents' choices on the contents/coverage of the topics of Writing III.

4. Part four revealed the topics of students' prefer.

5. Part five described students' preferences in teaching and learning activities.

6. Part six offered types of explanation which was the most helpful to be understood.

7. Part seven was time allocation.

8. Part eight was assessment system that wished by respondents.

9. Part nine dealt with problems encountered in writing III course.

10. Last part invited general comments or suggestions that respondents may have concerning any aspects of Writing III instruction.

In the questionnaire, the respondents were asked to give their responses by ticking $(\sqrt{ })$ a box representing their choice. Five different responses were offered to them; Strongly Agree (SA), Agree (A). Uncertain (U), Disagree (D), and Strongly 
Disagree (SD). It was used to describe the respondents' judgment about the statement.

In order to understand the collected data, they were going to be analyzed on the basis of their characteristics and purposes. The subjects' responses on the questionnaire were calculated in the form of percentages. Strongly Agree (SA) and Agree (A) belonged to positive responses, while Uncertain (U), Disagree (D), and Strongly Disagree (SD) were considered negative responses.

\section{FINDINGS}

\section{Results of Need Analysis}

The need survey was taken from legal document, and questionnaire toward the subject of the study. The subjects of the study were taken from B and D classes with 48 students who were taking Writing III class in the semester, the writing lecturers, and the chairman of English Education Study Program at IAIN Palangka Raya.

Need survey was carried out to describe the students' needs, interest, shortages as well as the chairman of English Education Study Program at IAIN Palangka Raya and Writing III lecturer's expectation to Writing III course. In this step, the researcher distributed questionnaires about the students' need on Writing III materials to the respondents. Each questionnaire consisted of 59 statements.

The items which related to instructional materials development were (1) objectives in taking Writing III class, (2) the contents of Writing III materials, (3) teaching and learning activities, (4) time allocation, (5) assessment procedures, and
(6) problems encountered in learning Writing III.

Meanwhile, the items which related to materials development were (1) sources, (2) topic of interest, (3) types of model text, (4) element/organization of materials, (5) type of explanation, and (6) exercises. The following was the result data collected through questionnaire responded by the fourth-semester students of English Education Study Program at IAIN Palangka Raya.

To conclude the objectives in taking Writing III class (Part I), both groups of respondents choose to be able to write a good essay covering the parts of the essay such as introduction, body, and conclusion $(52.9 \%)$. Therefore, majority of them chose to write various types of essay: illustration, classification, process, comparison and contrast, and cause and effect essays as the contents to be learned in Writing III course (58.8\%).

The other point in the questionnaire was the students' attitude and interest in writing skill (Part II). The model of writing from any sources was preferred mostly by the respondents (94.1\%). The other students' attitude and interest were as follows: writing ability was important in this global era $(88.3 \%)$; writing skill was important for them to get a job after graduated from English Education Study Program at IAIN Palangka Raya (100\%); writing articles for publication (e.g. published on wall magazines, newspapers, etc.) (82.3\%); and writing skill as important as speaking, reading, and listening skills (88.2\%).

Besides, the content of topics that must be taught in Writing III (Part III) course was the type of essay development such as illustration, classification, process, 
comparison and contrast, and cause and effect essays about $70.6 \%$. The other contents of the topics of Writing III were various types of essay such as: narrative, descriptive, expository, and argumentative about $64.7 \%$, and the structure of an essay, the elements of essay: unity and coherence about $52.9 \%$.

The next point in the questionnaire was the topics to be included in Writing III course (Part IV). Most respondents chose education (76.5\%) for the topics of students' prefer. The other respondents chose news $(64.7 \%)$, sports $(47.1 \%)$, entertainment $(64.7 \%)$, and social $(70.6 \%)$.

Dealing with the kinds of teaching and learning activities in the classroom (Part V), majority of the respondents thought that writing project was appropriately in teaching writing (88.2\%). The other activities were process of writing (brainstorming, drafting, revising, editing) $(52.9 \%)$, keeping diary journal $(58.8 \%)$, and focusing on grammar (41.2\%).

Furthermore, the respondents maintained that the brief explanation $(58.8 \%)$ and short tips $(64.7 \%)$ were the most helpful way in comprehending a writing theory (Part VI). The others were models/examples (47.1\%) and rules (47.1\%).

The other point in the questionnaire was that the sources to be included as instructional materials (Part VII) for Writing III course was variety of handouts $(64.7 \%)$. The others were from internet $(52.9 \%)$, and newspaper /magazines (47.1\%).

Related to this, stories or fiction $(64.7 \%)$ was the most interesting model text to stimulate writing (Part VIII). The others were advertisements (47.1\%) and news $(47.1 \%)$.

Both groups of respondents showed that the suitable writing exercises $(76.5 \%)$ were the elements/ organizations of the materials for Writing III course (Part IX). Some of them were model/ example $(64.7 \%)$, grammar/mechanics $(52.9 \%)$, and ideas organization $(58.8 \%)$.

Others were from the type of exercise for Writing III (Part X). Mostly respondents chose practice writing $(64.7 \%)$ as the type of exercise for writing III class. The others were guided composition (52.9\%), arranging jumbled paragraph $(52.9 \%)$, and developing ideas from the pictures $(52.9 \%)$.

The other point in the questionnaire was the time allocation (Part XI). Majority of respondents stated that 150 minutes allocated time per week for Writing III course was too long (58.8\%). Others stated 150 minutes allocated time per week was appropriate. The other stated 150 minutes was too enough (41.2\%).

The kinds of assessment that appropriate in assessing students' writing ability (Part XII) were product assessment and conducting middle and final test (70.6 $\%$ ). The others were ongoing process 'assessment (52.9\%), and product assessment (52.9\%).

The last, the problems encounter in Writing III course (Part XIII) were problems dealing with grammar, vocabulary mechanics, and punctuation $(58.8 \%)$. The others were problems dealing with paragraph $(52.9 \%)$, and problems dealing with sentence constructions $(47.1 \%)$.

Based on the results above, it could be concluded that the materials of Writing III course need to be provided instructional 
materials. For this purpose, the $\mathrm{R}$ and $\mathrm{D}$ on developing instructional Writing III course material was conducted.

\section{Description of the Purpose}

The students needed to enhance their mastery in essay writing skills which had several topics included, to be able to compose an essay. Moreover, in order to gain the mastery of essay writing skill, the developed syllabus provides students with process writing such as prewriting, drafting, and revising in order to gain better writing products. Since, the syllabus of Writing III was already existed; the researcher proposed the developed materials based on the existing syllabus.

\section{Selection and Development of Material Type}

The selected type of material was the writing material using graphic organizers. The characteristics of this type which emphasized on organizing Writing III course around skills and process such as generating ideas, organizing ideas, and revising seemed correspond to the developed material which was designed to have skills in writing through process writing. Therefore, the instructional writing material using graphic organizer was considered representative for the developed instructional material.

\section{Production of Proto-Material}

The proto- material was also as a first draft in the material development. The content was specified on the (1) the structure of an essay (2) illustration essay, (3) classification essay (4) process essay, (5) comparison and contrast essay, and (6) cause and effect essay. The skills to master in Writing III course were the ability to write an essay and develop the essay using various developments: illustration, classification, process, comparison and contrast, and cause and effect essay. The method to apply was process writing which led the students to write an essay including prewriting, whilst writing and post writing. The procedures the writing lecturer could do to measure the students' achievement were the process in the teaching and learning activity and the products produced by students as well as doing the quiz, middle and final test. The time allotment for each meeting was 150 minutes.

\section{Production of Pedagogical Material}

The covered objective, strategy, evaluation method, and time framework. When the pedagogical material finished, it would be the basis to develop some instructional materials.

\section{The Expert Validation}

The product was validated by the two experts before being tried out. The expert validators selected to validate the materials since they had long experience in teaching writing for years, and they were known as an expert and senior English lecturers at university level. The first expert validator focused on content of the material development. Meanwhile, the second expert validator focused on assessment of the material development.

The validation of the product covered some aspects such as design, objectives, topics, organization, content, coverage, language, instruction, example, and exercise. After several consultations and revisions, both expert validators declared that the developed instructional materials 
had been validated after having passed both verification and revision.

\section{Field Testing (Trying-out)}

After having validated by experts, the text step was to conduct field testing. The instructional materials were used in the classroom as a handout for the students, as a guide for the theories, brief explanation, practicing, more examples, graphic organizer, and also assessment for the students.

The students in class B who participated in try-out stage for fourth meetings were given a questionnaire to assess their opinions on the instructional materials. The questionnaires were modified from Purwaningtyas' questionnaires (Purwaningtyas, 2007:79). They were asked to give a checklist on the provided column for Strongly Agree, Agree, Uncertain, Disagree, and Strongly Disagree that represented their choices and attitude.

In addition, based on the statistical result of try out for the instructional materials, it was shown that before the instructional materials were implemented, the mean of the students' writing score was 5.98. Then, after the instructional materials were implemented, the mean of the students' writing score was 6.96. Based on the statistical calculation, it was found that the $\mathrm{t}$ value was 8.639. It was also found that the $\mathrm{df}$ (Degree of freedom) of the distribution observed was $48-1=47$. Based on the Table of $t$ value, if df was 47 , the $5 \%$ of significant level of $t$ value was at 1.648 and the $1 \%$ of significant level of $t$ value was at 2.423 . It could be seen that $t$ table $(5 \%=1.648)<\mathrm{t}$ value $(8.639)$. It meant that the $t$ value empiric at 8.639 was greater than $t$ theoretic at the $5 \%$ and $1 \%$ of significant level. Based on the results, it could be concluded that at the $5 \%$ and $1 \%$ of significant level, there was a very significant difference on students' writing score between before the implementation of instructional materials (Mean $=5.98)$ and after the implementation of instructional materials (Mean=6.96).

This meant that Ha stating that there was a significant difference on students' writing score between before the implementation of instructional materials and after the implementation of instructional materials was accepted. On the contrary, Ho stating that there was no significant difference on students' writing score between before the implementation of instructional materials and after the implementation of instructional materials was rejected. It meant that instructional materials gave facilitative effect on the students' essay writing performance. To sum up, the means differed significantly at $1 \%$ and $5 \%$ significant level.

Table 1. The sample Statistics of Graphic Organizer

Paired Samples Statistics

\begin{tabular}{|c|c|c|c|c|c|}
\hline & & Mean & $\mathrm{N}$ & $\begin{array}{c}\text { Std. } \\
\text { Deviation }\end{array}$ & $\begin{array}{l}\text { Std. Error } \\
\text { Mean }\end{array}$ \\
\hline \multirow{2}{*}{\multicolumn{2}{|c|}{\begin{tabular}{|l} 
Pair 1 \\
\\
1 \\
\\
\\
\\
\\
2
\end{tabular}}} & 5.9792 & 48 & .83767 & 12091 \\
\hline & & 6.9583 & 48 & .92157 & 13302 \\
\hline
\end{tabular}

120 | Journal on English as a Foreign Language, Volume 5, Number 2, September 2015 
Paired Samples Correlations

\begin{tabular}{|l|r|r|r|}
\hline & $\mathrm{N}$ & $\begin{array}{c}\text { Correlatio } \\
\mathrm{n}\end{array}$ & Sig. \\
\hline $\begin{array}{l}\text { Pair 1 VAR00001 \& } \\
\text { VAR00002 }\end{array}$ & 48 & .605 & .000 \\
\hline
\end{tabular}

\section{Evaluation and Revision}

\section{Evaluation from Try-out}

After having tried out, the next step was to evaluate and revise the developed instructional materials. Based on the results of try-out, it was found that instructional materials gave facilitative effect on the students' essay writing performance.

Based on the students' try out, they suggested as follows: (a) the materials are not enough for one meeting, (b) the examples more interesting, (c) the detail explanation should cover in the next practices, and (d) the explanation and the tips are attract them.

\section{Evaluation from the Expert}

Based on the expert validation, both expert validator suggested as follows: (a) to add more examples for each model of essays, (b) to aware with language aspect and expression, (c) the layout of the product should be interesting and (d) to give more explanations for each meeting.

\section{Final Product}

After having evaluation and revision, the last step was to produce final product. The final product was written based on the first draft of material development after being validated, tried- out and evaluated and revised. The final product of Writing III course materials consisted of six units covering introduction to the essay (unit 1 for meetings 1-4), the illustration essay (unit 2 for meeting 5), the classification essay (unit 3 for meeting $6)$, the process essay (unit 4 for meeting 7), the comparison contrast essay (unit 5 for meeting 8), and the cause and effect (unit 6 for meeting 9). Each unit consisted of learning objective, topic, sub-topic, description, relevancy, and keywords.

\section{DISCUSSION}

The results of this study confirmed with Tang (1992:178) who pointed out that dual coding function of graphic organizers provide learners with both visual and verbal information. The visual information contains the knowledge of the content while the verbal information promoted language acquisition.

In line with the effectiveness of the materials of Writing III course using graphic organizers for the students of English Education Study Program at IAIN Palangka Raya. In addition, the results of the study show that before the instructional materials were implemented, the mean of the students' writing score was 5.98. Then, after the instructional materials were implemented, the mean of the students' writing score was 6.96. Based on the statistical calculation, it was found that the $t$ value was $8.639(p<000)$. There was a very significant difference on students' writing score between before the implementation of instructional materials (Mean=5.98) and after the implementation of instructional materials (Mean=6.96). 
Here, the students in the learning process are interested in joining the writing class using graphic organizers. For them, it is a new model of pre-writing strategies. The class becomes more interesting when the researcher shows them various models of graphic organizers. By using graphic organizers, the students can easily map the ideas to be developed in writing essay. They are also helped in generating ideas before starting to write. At the end of class, the students can write an essay better than the previous strategy.

The result of this study is also congruent with Hawk (1986:85) who examined the effectiveness of graphic organizer as an advance organizer on science students' achievement. The result showed a statistically significant main effect $(p<.001)$ in favor of the students who received instruction using graphic organizers. The conclusion drawn from this study was that the graphic organizer is an effective and practical teaching strategy.

Also, graphic organizer has roots in Ausubel's meaningful reception learning, reception learning can be meaningful when: (a) the learner relates new

\section{REFERENCES}

Ellis, E. S. (2001). Make sense strategies: Connecting teaching, learning and assessment (computer software). Tuscaloosa, AL: Masterminds publishing.

Hawk, P. (1986). Using graphic organizers to increase achievement in middle school life science. Sience Education, $70(1), 81-87$. information to individual prior knowledge. Clearly, prior knowledge plays a central role in Ausubel's meaningful learning. Finally, the results of the study are also in tune with Ellis (2001) who noted that information is more easily learned and comprehended with visual organizers.

\section{CONCLUSION}

The final version of the product consists of Writing III instructional materials for nine meetings. The materials serve for appropriate topics, clear models, stimulating learning, relevant activities, clear example, graphic organizers, and providing strategies. The final product of writing III course materials consist of six units covering introduction to the essay (unit 1 for meetings 1-4), the illustration essay (unit 2 for meeting 5), the classification essay (unit 3 for meeting 6), the process essay (unit 4 for meeting 7), the comparison contrast essay (unit 5 for meeting 8), and the cause and effect (unit 6 for meeting 9). Each unit consists of learning objective, topic, sub-topic, description, relevancy, and keywords.

Hyland, K. (2003). Second language writing. Cambridge: Cambridge University Press.

Prodi Tadris (Pendidikan) Bahasa Inggris STAIN Palangka Raya. (2011). Kurikulum program studi tadris (pendidikan) bahasa Inggris jurusan tarbiyah STAIN Palangka Raya. Palangka Raya: Prodi TBI STAIN Palangka Raya.

Purwaningtyas, I. (2007). Designing syllabus and instructional materials of 
writing I for S-1 English literature of language and literature program of Brawijaya University. Unpublished Thesis. Malang: University of Brawijaya, Malang.

Richard, J. (2001). Curriculum development in language teaching. Cambridge: Cambridge University Press.

Smalley, R. L. \& Reutten, M. K. (1986). Refining composition skills: Rhetoric and grammar for ESL students. New York: Macmillan Publishing Company.

Tang, G. (1992). The effect of graphic representation of knowledge structures on ESL reading comprehension. Studies in Second Language Acquisition, 15, 177-195.

Tomlinson, B. (2001). Materials development. In Carter, C. \& Nunan, D. (Eds). The Cambridge guide to teaching English to speakers of other languages (Pp. 66). Cambridge; Cambridge University Press.

Ur, P. (1996). A course in language teaching: Practice and theory. Cambridge: Cambridge University Press.

Yalden, J. (1987). The communicative syllabus: Evaluation, design $\mathcal{E}$ implementation. New York: Pergamon. 
124 | Journal on English as a Foreign Language, Volume 5, Number 2, September 2015 